\title{
Botanical description, phytochemistry, traditional uses, and pharmacology of Crataeva nurvala Buch. Ham.: an updated review
}

\author{
Dinesh Kumar ${ }^{1,2^{*}}$, Shivangi Sharma ${ }^{1}$ and Sunil Kumar ${ }^{1}$
}

\begin{abstract}
Background: Crataeva nurvala Buch. Ham., an important medicinal plant of the Capparidaceae family, is widely distributed in India and tropical and subtropical parts of the world. It has been reported for its folkloric use in various disorders such as blood purifier, breathing problems, fever, metabolic disorders, wound healing, memory loss, and weak immune system.

Results: The present review has focused on the botanical description and ethnomedicinal and traditional uses of $C$. nurvala along with its reported pharmacological activities. Chief chemical constituents and pharmacological aspects of C. nurvala have been deeply explored to unravel the unexplored folklore/ethnomedicinal uses of this plant so that the researchers working on this plant may be able to find new insights to continue further investigation on this plant. The pharmacological aspects like anti-diabetic, anti-inflammatory, anti-nociceptive, anti-diarrheal, antifertility, anti-pyretic, and anti-cancer potentials evaluated by various in vitro/in vivo methods on this plant have been reported.

Conclusion: Various traditional uses have been reported that need to be scientifically investigated in depth and several pharmacological activities have been reported for the C. nurvala, but more detailed and mechanism-based studies linked to a particular lead compound need to be targeted in the future. Moreover, this plant has not been completely assessed on the basis of its safety and efficacy on humans. It is expected that this review will compile and improve the existing knowledge on the potential utilization of $C$. nurvala in complementary and alternative medicine.
\end{abstract}

Keywords: Crataeva nurvala, Botany, Traditional use, Phytochemistry, Pharmacology

\section{Background}

According to an estimate, $75 \%$ of the overall population practices plants or their extracts for their curative capabilities [1]. Furthermore, around $80 \%$ of the developing countries of the world rely on traditional medicines, mainly plants or their products, for their basic healthcare

\footnotetext{
* Correspondence: dineshbarbola@kuk.ac.in

${ }^{1}$ Institute of Pharmaceutical Sciences, Kurukshetra University, Kurukshetra, Haryana 136119, India

2Department of Clinical Biochemistry and Pharmacology, Ben-Gurion University of the Negev, 84105 Beer Sheva, Israel
}

needs [2]. In the present situation, it is estimated that medicinal plants, as well as their products contribute up to $50 \%$ of all drugs being used in medical practices [3].

Since the beginning of human life, plants and plantderived compounds have been utilized in several diseases or ailments throughout the world. In the present time, most of people in this world still have faith in their traditional herbal medicine (medicinal plants and or their derived materials) for their routine health-related problems. World Health Organization (WHO) states that this "traditional medicine" implies the knowledge and

\section{Springer Open}

(c) The Author(s). 2020 Open Access This article is licensed under a Creative Commons Attribution 4.0 International License, which permits use, sharing, adaptation, distribution and reproduction in any medium or format, as long as you give appropriate credit to the original author(s) and the source, provide a link to the Creative Commons licence, and indicate if changes were made. The images or other third party material in this article are included in the article's Creative Commons licence, unless indicated otherwise in a credit line to the material. If material is not included in the article's Creative Commons licence and your intended use is not permitted by statutory regulation or exceeds the permitted use, you will need to obtain permission directly from the copyright holder. To view a copy of this licence, visit http://creativecommons.org/licenses/by/4.0/. 
practices of herbal healing for the prevention, diagnosis, and elimination of physical, mental, or social imbalance [4]. Plants have always been an exemplary source of drugs and many of the currently available drugs have been derived directly or indirectly from them. About $25 \%$ of the drugs prescribed worldwide come from plants, 121 such active compounds being in current use. Of the 252 drugs considered basic and essential by WHO, $11 \%$ are absolutely of plant origin and a significant number are synthetic drugs derived from natural precursors. Some of important drugs obtained from plants include artemisinin from Artemisia annua L., atropine from Atropa belladonna, digoxin from Digitalis sp., quinine and quinidine from Cinchona sp., morphine and codeine from Papaver somniferum, and vincristrine and vinblastine from Catharanthus roseus [5-7].

The genus Crataeva was named in honor of the Greek botanist "Crataevas" and includes about 70 species dispersed mainly in the warmer parts of the world. Among them, C. nurvala displays the highest bio-diversity in India [8]. C. nurvala has been an important ingredient of various herbal formulations. "Uriflow" a commercial herbal formulation comprising C. religiosa bark has shown remarkable performance in removing renal and bladder stones. The efficacy of "Himplasia" a polyherbal formulation of Himalaya herbal healthcare has been reported in enlarged prostate problem [9]. "Renaloka" product of Himalaya herbal health care is prescribed and used in for urinary tract infection [10]. Another preparation named "Varunal" containing Crataeva in combination with Eclipts, Picrorrhiza, Achillea, Cichorium, Solanum, Arjuna, and Cassia is useful in the treatment of arthritis, ascites, edema, hepatitis, and urinary stones [11].

\section{Main text}

\section{Geographical description}

It is a medium-sized, ornamental, deciduous tree, $6-10 \mathrm{~m}$ tall, found either wild or cultivated throughout India, especially in the semi-arid regions [12]. This plant is one of the eleven species within the family Capparidaceae, including trees, shrubs, and, rarely, herbs, which are distributed in the warm, tropical, and occasionally arid regions of both hemispheres [13]. This plant is distributed in India, Sri Lanka, Myanmar, Malaysia, Indonesia, and China. It is also found in Sikkim and Andman and Nicobar Island [14]. It is found mostly along the bank of the river and streams and near the temple sides $[15,16]$. In India, it is usually cultivated in Assam, Bengal, Central India, and near river banks in Kanara and Malabar. This plant usually grows in the southernmost mountains in the Himalayan range and is indigenous to Karnataka, Kerala, and Tamil Nadu. This plant usually bears flowers in March and fruits in June every year [17-19]. C. nurvala regularly grows throughout India along with tropical and subtropical countries of the world [20].

\section{Botanical description}

Crataeva nurvala Buch. Ham. (Family: Capparidaceae) having synonyms C. magna, C. religiosa or C. roxburghii is commonly known as the three-leaved caper [Eng.], Baruna [Hindi], Barna [Punjabi], Borun [Bangali], Bilvaram [Telgu], Varun [Sanskrit], Narvala [Kannada], Ramala [Marathi], Vayavarna [Gujrati], and Varanam [Tamil] in different regions of India [17-19].

\section{Taxonomy}

About 70 species of genus Crataeva are scattered mainly in different parts of the world. However, nurvala species of this pant shows exorbitant growth. The taxonomical data of this plant is detailed below [8]:

Kingdom: Plantae

Division: Magnoliophyta

Phylum: Tracheophyta

Class: Magnoliopsida

Order: Brassicales

Class: Magnoliopsida Brongniart

Family: Capparidaceae

Genus: Crataeva

Species: Nurvala

\section{Macroscopic characteristics}

This plant is a medium-sized, deciduous tree (approx. $30 \mathrm{~m}$ height) having much branched head. Leaves being three-foliated with petioles $(3.8$ to $7.6 \mathrm{~cm})$ bear leaflets which are ovate, entire, lanceolate/obovate, acute/or acuminate, and reticulately veined, the lateral leaflets with petiole $69 \mathrm{~mm}$ long $[8,20]$.

The developed bark is generally 6 to $15 \mathrm{~cm}$ in length and 3 to $10 \mathrm{~cm}$ in width with a thickness of 5 to $15 \mathrm{~mm}$. The bark outer side is rough and appears gray to grayish brown whereas the inner side is suave and whitish brown to pale in appearance. Flowers may be whitish cream, pale yellow, or reddish yellow colored, appearing either just before or with the leaves. Fruits are spherical or oval, hard, slim, or scaly berry. Fruits have multiple reniform seeds which are implanted in the yellow and fleshy pulp of the fruit [17, 21-24].

\section{Histological characteristics}

Transverse section of the fully developed stembark displays outer cork with thin-walled, rectangular or tangentially stretched cells, unilayered phellogen, thin walled, tangentially stretched cells and then, widespread secondary cortex, made up of thin-walled, elongated cells which may be polygonal or tangential in shape. Plentiful stone cells in groups appear disseminated throughout secondary cortex. Stone cells may be circular to rectangular or elongated in shape and are scattered in the phloem region. Secondary phloem being a broader part comprises of companion cells, parenchyma, sieve tubes, and stone 
cells. Medullary rays are generally multi-seriate. Some rhomboid-shaped calcium oxalate crystals are seen [24].

\section{Traditional/ethnomedicinal uses}

In Ayurveda, C. nurvala Buch-Ham is known as Tikta saka (due to bitter taste of leaves), Setu briksh (due to its expulsive property of renal calculus), Kumarak (as its leaves remain younger for many days) and Sweta puspa due to its whitish flower [22, 25-27]. According to Bhav Prakash Nighantu, this plant enhances Pitta, soften and expels hardened feces, cures the diseases of Kapha and Vata, and suppresses difficulty in micturation and urolithiasis. It mitigates intestinal growths and Vata and Rakta diseases [28].

In Ayurvedic system of medicine, C. nurvala is widely used in various treatments. This plant has been extensively used in traditional medicines as a blood purifier and in treating cardiac and lung weakness, fever, joint problems, blood flow, memory loss, respiratory complications, metabolic syndromes, wound healing, and weak immune system. Folklore uses recommend its applications as an anti-periodic, bitter tonic, diuretic, laxative, and oxytocic drug $[8,29,30]$.

Leaves are stomachic, very good counter-irritant, rubefacient (external use), febrifuge, and tonic (internal use) and are used in rheumatism [18, 31, 32]. Leaves along with root paste have been used in abscess, cervical adenitis, edematous wounds, and reducing body fat. Its leaf pulp has been reported to show significant benefit in spleen enlargement, when applied on stomach. The leaf decoction, when administered along with ghee, gets rid of flatulence and stomach pain. This plant also works as an appetizer and cholegogue and hence advantageous in anorexia, helminth infections, hepatic ailments, flatulent dyspepsia, and tumors [24]. In the Philippines, C. nurvala leaves are traditionally used by tribal females during irregular menstruation [8]. This plant is beneficial as an antiinflammatory, anti-pyretic, anthelminthic, demulcent, diuretics, and stomachic; for urinary organs disorders; and as a noble contraceptive for females [33, 34].

Both root and bark of $C$. nurvala are laxative and lithotriptic, promote appetite, and increase biliary secretion. Bark is used in chest infection, fevers, vomiting, urinary stone, thyroid disorder, obesity, cancer, gastric irritation, snake-bite, and convulsions. Stem bark has been widely incorporated in various formulations recommended for kidney stone, prostatic enlargement, and bladder and urinary manifestations. The stem bark is reported to have anti-inflammatory effect and stimulates appetite, bile secretion, and bowel moment [12, 18, 3537]. Some of the traditional uses of $C$. nurvala have been mentioned in Table 1.

\section{Phytochemistry}

Detailed phytochemical analysis reveals the occurrence of alkaloids, anthracene derivatives, flavonoids, phenolics, phytosterols, saponins, tannins, triperpenoids, and volatile oils $[8,38]$. The leaf has been reported to contain dodecanoic anhydride, kaempferol$\mathrm{O}-\alpha$-D-glucoside, methyl pentacosanoate, isoquercetin, quercetin, quercitin-3-O- $\alpha$-D-glucoside, rutin, and $\mathrm{L}$ stachydrine $[2,31]$. The root bark contains $\beta$ epilupeol, $\beta$-sitosterol, $\beta$-sitosterol acetate, lupeol, $\gamma$ taraxasterol, quercetin, rutin and varunol along with lauric, stearic, undecyclic, and oleic and lenoleic acids $[17,20,34]$. The stem bark contains betulinic acid, (-)-catechin, cetyl alchol, diosgenin, (-)-epiafzelechin, (-)-epiafzelechin 5-O- $\beta$-D-glucoside, friedelin, glucocapparin, lupeol, and $\beta$-sitosterol. The alkaloids like

Table 1 Traditional uses of C. nurvala

\begin{tabular}{|c|c|c|c|}
\hline S. No. & Plant part(s) & Formulations & Uses \\
\hline \multirow[t]{4}{*}{1.} & Leaves & Leaf juice with coconut milk and ghee & Rheumatism $[18,31,32]$ \\
\hline & & $\begin{array}{l}\text { Poultice/paste of fresh leaves with little vinegar, } \\
\text { lime juice or lime water, or hot water is prepared }\end{array}$ & $\begin{array}{l}\text { Rubefacient effect on skin and as vesicant, } \\
\text { for longer use }[31,32]\end{array}$ \\
\hline & & Leaf paste & $\begin{array}{l}\text { Applied to soles of feet to relieve swelling } \\
\text { and burning sensation }[18,31,32]\end{array}$ \\
\hline & & Leaf decoction & Flatulence and stomach pain [24] \\
\hline \multirow[t]{2}{*}{2.} & Stem bark & $\begin{array}{l}\text { Decoction of bark prepared by bruising and boiling } \\
4 \text { ounces of bark in } 11 / 2 \text { pints of water till reduced } \\
\text { to } 1 \text { pint and then strained and cooled }\end{array}$ & $\begin{array}{l}\text { Useful in bladder stone, fever, vomiting, } \\
\text { gastric irritation. and as tonic }[8,18,35-37]\end{array}$ \\
\hline & & Decoction of bark & $\begin{array}{l}\text { Useful in scrofulous enlargement of glands } \\
\text { under lower jaw and swollen testicles } \\
{[8,18,35-37]}\end{array}$ \\
\hline 3. & Root and bark & Embrocation formed by boiling root and bark in oil & Reduced body pain and strain $[8,18]$ \\
\hline 4. & Root, bark, and Leaves & $\begin{array}{l}\text { Compound decoction of root, bark, leaves with } \\
\text { ginger, carbonate of potash, honey and water }\end{array}$ & $\begin{array}{l}\text { Effective in ascites, urinary disorders, calculous } \\
\text { affection }[8,18,35-37]\end{array}$ \\
\hline 5. & Leaves and Root & Mixed with cocoanut juice and ghee, served as food & Reduce corpulence [35] \\
\hline
\end{tabular}


cadabicine, cadabicine diacetate, and cadabicine mether have also been reported in the stem bark [15, 39]. The fruits contain cetyl alcohol, gluco-capparin, octanamide, pentadecane, 12 tricosanone and friedelin triacontanol, triacontane, $\beta$-sitosterol [40-42]. Chief phytoconstituents reported in this plant have been mentioned in Fig. 1. The occurrence and biological significance of main phytoconstituents is discussed below:

\section{Beta-sitosterol}

Beta-sitosterol is the most common dietary phytosteol found in plant-based foods such as fruits, vegetables, soybeans, breads, peanuts, and peanut products [43]. It has been shown to be responsible for anti-oxidant, anticancer, anti-diabetic, androgenic, anti-gonadotrophic, anti-HIV, anti-hypercholesterolemic, anti-mutagenic, anti-prostatic, anti-rheumatic, anti-atherosclerotic, and immunosuppressant effects [44-48].

\section{Betulinic acid}

It is a naturally occurring pentacyclic lupane-type triterpenoid, usually isolated from trees of Betulaceae family. It exists both as a free aglycone and as glycosyl derivatives [49]. It exhibits various pharmacological properties such as anti-bacterial, anti-malarial anti-parasitic [50], anti-HIV [51, 52], anti-inflammatory [53], anti-microbial, anti-hyperlipidemic [54], cytotoxic and anti-tumor [55, 56], and anti-diabetic effects [57].

\section{Catechin}

It is a flavonol mainly present in tea leaves, red wine, broad beans, black grapes, strawberries, and apricots [58, 59]. The four main catechins of green tea are (-)-epicatechin, (-)-epicatechin-3-gallate, (-)-epigallocatechin, and (-)-epigallocatechin-3-gallate and reported to have good anti-microbial properties [60]. It exhibits biological properties namely anti-bacterial, anti-oxidative, antiproliferative, and chemopreventive effect [61-63].

\section{Diosgenin}

Along with $C$. nurvala, diosgenin is also present in large quantities in many plant species including Costus speciosus, Smilax menispermoidea, species of Paris, Aletris, and Trillum, and in species of Dioscorea [64]. It is used as natural raw material for the preparation of steroidal drugs and contraceptives and reported to have anticancer [65], anti-inflammatory [66], anti-oxidant [67, 68], cardiovascular protective [69], hypolipidemic [70], and neuroprotective effects .

\section{Friedelin}

Friedelin is a triterpenoid showing several biological activities such as anti-oxidant, hepatoprotective [71], antiinflammatory, anti-pyretic, anti-carcinogenic effects [72,
73], anti-obesity [74], anti-mycobacterial [75], and gastroprotective [76] activities. Lee et al. reported that Friedelin improves bioavailability of apigenin by suppressing ATPase activity of P-glycoprotein when co-administered with it [77].

\section{Kaempferol}

It is a tetrahydroxyflavone containing four hydroxy groups at positions $3,5,7$, and $4{ }^{\prime}$. It found, in addition to $C$. nurvala, many edible plants (e.g., beans, broccoli, cabbage, grapes, tomato, strawberries, and tea) and in plant products frequently used in traditional medicine, e.g., Ginkgo biloba, Tilia spp., Equisetum spp., Moringa oleifera, and Sophora japonica and propolis [78]. Kaempferol and its glycosylated derivatives are reported to have anti-oxidant, anti-diabetic, anti-microbial, anti-inflammatory, antitumor, anti-cancer, cardioprotective, and neuroprotective activities [79].

\section{Lupeol}

Lupeol is a pentacyclic triterpene obtained from other rich sources like mango pulp, grape, hazel nut, olive oil, carrot root, cucumber, and soybean cabbage in addition to C. nurvala. It possesses anti-inflammatory, antiinvasive, anti-angiogenic, anti-arthritic, anti-microbial, anti-protozoal, anti-diabetic, and cholesterol-lowering effects $[50,80]$. It is also reported to have significant anti-oxidant, anti-hyperglycemic, anti-edemic, antihepatotoxic, anti-tumor, chemoprotective, cytotoxic, and hypotensive activities [81, 82].

\section{Quercetin}

Its naturally occurring polyphenol is mostly present in the form of quercetin glycosides [83]. It is useful in cardiovascular diseases, diabetes, asthma, and viral infections and has shown anti-hypertensive, antiinflammatory, anti-oxidant, anti-histaminic, anti-cancer, anti-cataract, anti-ulcer, anti-aging, anti-allergic, antiobesity, and cytotoxic effects [84-86].

\section{Rutin}

The name rutin comes from the plant Ruta graveolens, but buckwheat is considered the main natural source $[87,88]$. It is a glycoside comprising flavonolic aglycone quercetin along with the disaccharide rutinose. The main pharmacological activities of rutin include antioxidant, cardioprotective, cytoprotective, cytotoxic, and neuroprotective activities [89-91].

\section{Stachydrine}

Stachydrine is also highly present in Leonurus japonicus, L. cardiaca fruits, and Leonotis leonurus as well as in citrus fruits in addition to $C$. nurvala. It has effectively reduced lipopolysaccharide-induced endothelial inflammatory 
<smiles>Oc1cc(O)c2c(c1)OC(c1ccc(O)c(O)c1)C(O)C2</smiles>

Catechin

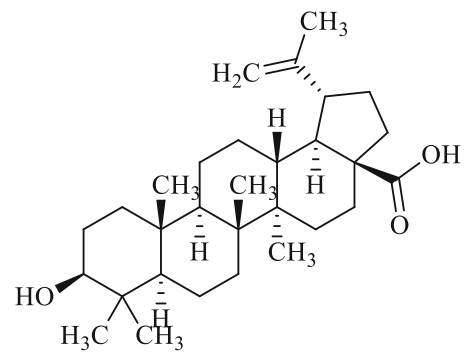

Betulinic acid<smiles>OCC1O[C@@H](Oc2cc(O)cc3c2C[C@@H](O)[C@H](c2ccc(O)cc2)O3)C(O)[C@@H](O)[C@@H]1O</smiles><smiles>C[C@H]1C(=O)CC[C@]2(C)[C@]1(C)CC[C@]1(C)C3CC[C@]4(C)C5CC(C)(C)CC[C@]5(C)CC[C@]4(C)C3CC[C@]12C</smiles>

(-)-Epiafzelechin 5-O- $\beta$-D-glucoside

Friedelin<smiles>C=C1C(O)=C(c2ccc(O)cc2)Oc2cc(O)cc(O)c21</smiles>

Kaempferol

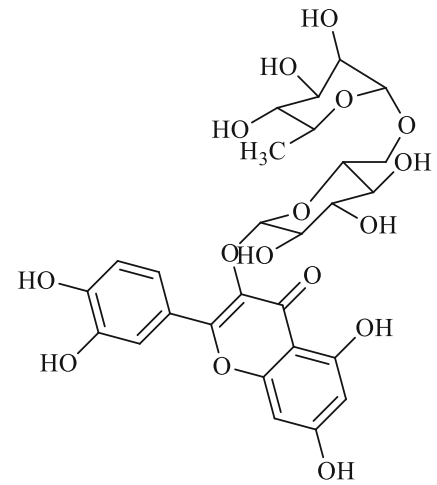

Rutin

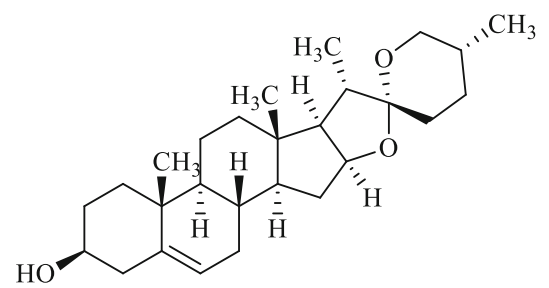

Diosgenin<smiles>C/C(=N/OS(=O)(=O)O)S[C@@H]1O[C@H](CO)[C@@H](O)[C@H](O)[C@H]1O</smiles>

Glucocapparin<smiles>CCCC(CC)C(C)CC</smiles>

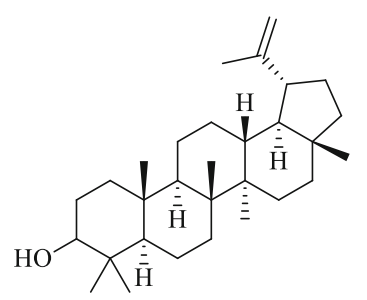

Lupeol

Kaempferol 3-O- $\alpha$-D-glucoside<smiles>CCC[C@@H](CC)C(C)C</smiles><smiles>CC[C@H]1CC[C@H]2[C@H]3CC=C4C[C@@H](O)CC[C@]4(C)[C@H]3CC[C@]12C</smiles>

$\beta$-sitosterol<smiles>CCN1CCCC1C(=O)[O-]</smiles>

Stachydrine

Tricontanol<smiles>CCCCCCCCCCCCCCCCCCCCCCCCCCCCCCC</smiles>

Tricontane

Fig. 1 Chief bioactive phytoconstituents isolated from C. nurvala 
response via the inhibition of interleukin (IL-10) and thromboxane B 2 (TXB2) secretion [92]. Stachydrine has shown various bioactivities namely anti-fibrosis, cardioprotective, anti-cancer, uterine regulator, neuroprotective, antiinflammatory [93], anti-gynocological, and renoprotective effects [94].

\section{Pharmacological activities}

Owing to its widespread traditional and medicinal uses, C. nurvala has been exploited for various pharmacological activities as mentioned below:

\section{Anti-inflammatory effect}

C. nurvala ethanol extract negatively controls signal transduction extracellular kinase signals in rat macrophages, inhibiting the inflammatory response triggered by lipid polysaccharides. Non-cytotoxic concentrations of the extract considerably decrease the production of nitric oxide and interleukin-6, in macrophages inspired by lipid polysaccharides. After decreasing the production of inflammatory mediators using the extract, the kinase activity is controlled by mitogen-activated protein kinase, in particular extracellular signal transduction [95, 96]. Studies have reported that lupeol, when administered topically, reduces inflammation caused by $12 \mathrm{O}$ tetradecanoyl phorbol acetate in a mouse ear model and decreases the invasion of cells in the inflammatory tissues of mice by reducing the level of myeliferoxidase (specific markers of neutrophils). Lupeol application (5 to $9.37 \mathrm{mg} \mathrm{kg}^{-1}$ ) has shown to produce maximum inhibition (57.14\%) of inflammation [97-100].

\section{Anti-fertility activity}

It has been reported that aqueous and ethanol extracts from the dried stems of $C$. nurvala Buch-Hum produce a significant effect on infertility in rats. These extracts (300 and $600 \mathrm{mg} / \mathrm{kg}$ ) displayed partial and complete absorption of implants. The alcoholic extract proved to be more potent than the aqueous one. On the other hand, while evaluating the effect on estrogen level, both extracts were found to increase the uteri weight and caused the vaginal opening in immature mice, thus substantiating its effect on the prevention of pregnancy in mice $[8,101]$.

\section{Anti-arthritic activity}

The intraperitoneal administration of isolated lupeol and its esters $\left(50 \mathrm{mg} \mathrm{kg}^{-1}\right.$ ) obtained from $C$. nurvala showed a protective effect against arthritis induced by FCA in leg swelling in rats and compared with standard indomethacin. Lupeol has been found to temper the action of numerous molecules like cytokines, protease, alphaglucosidase, cFLIP, Bcl-2, and NF-kB [102, 103].

\section{Anti-diarrheal activity}

The $C$. nurvala ethanol bark extract $\left(500 \mathrm{mgkg}^{-1}\right.$, i.p.) expressively decreased the excreta production and excretion rate compared to rats not treated with castor oil and compared with atropine $\left(3 \mathrm{mg} \mathrm{kg}^{-1}\right)$. The extract also significantly slows down intestinal transit and castor oil-induced enteropooling, therefore producing antidiarrheal activity [104].

\section{Cardioprotective activity}

In some previous studies, lupeol, isolated from this plant bark when administered $\left(50 \mathrm{mg} \mathrm{kg}{ }^{-1}\right)$ for 10 days to investigate protective effect on myocardium against cyclophosphamide (200 mg kg $\mathrm{kg}^{-1}$ i.p.), showed cardioprotective effect which might be owing to the anti-oxidant properties of its triterpenes [105-107].

\section{Anti-urolithic property}

In albino rats, the plant decoction was reported effective in preventing stone formation. It also decreased the $\mathrm{pH}$ of urine making it acidic. Therefore, it can be concluded that this plant is useful in reducing the recurrence of urolithiasis [107-109]. In another study, lupeol (50 mg/ $\mathrm{kg}$ ) produced strong in vivo anti-urolithiatic effect. Decoction of this plant $\left(800 \mathrm{mg} \mathrm{kg}^{-1}\right)$ also increases contractile strength and decreases the remaining urine load in patients with an enlarged prostate [12].

\section{Anti-nociceptive activity}

C. nurvala bark ethanol extract (250-500 $\mathrm{mg} \mathrm{k}^{-1} \mathrm{~g}$, per orally (p.o.) showed the anti-nociception in acetic acidinduced analgesia model, thus indicating its use in the treatment of rheumatic inflammatory conditions [110].

\section{Anti-diabetic activity}

C. nurvala stembark alcoholic extract significantly decreased blood glucose in alloxan-persuaded diabetic rats. The petroleum ether and ethanol extracts showed significant anti-diabetic effect $(p<0.001)$, and also prohibited weight loss in diabetic animals $[111,112]$.

\section{Anti-cancer activity}

Lupeol (40 mg kg-1), when applied topically, not only reduced tumor growth but also increased tumor latent duration in the mice and inhibited tumor growth that directed transduction of the NF-kB 67 signal affecting the invasion of two cervical cancer cells. Its anti-tumor effect was also investigated in human hepatocyte carcinoma cells where it inhibited the growth of cells and caused their death as a result of apoptosis which in turn was caused by a decrease in DR3 expression in cells $[113,114]$.

In an in vitro study, the plant ethanol extract was tested on A549 cell line (human lung cancer), the HeLa cell line (cervix uteri), and the MDA-MB cell line 
(human adenocarcinoma, mammary gland). Extract showed encouraging anti-cancer effect. Percent cell lysis was found in the range closer to the standard for all the cell lines and optical density at $492 \mathrm{~nm}$ as (0.575 to 1.191) almost equal to that of reference standard, i.e., 1.151 and always more than blank. The $\mathrm{IC}_{50}$ values were obtained to $<10,13$, and $20 \mu \mathrm{g}$ against A549, HeLa, and MDA-MB cell lines. These findings suggest that $C$. nurvala bark extract possesses good anti-cancer activity [115].

\section{Anti-pyretic activity}

The root bark ethanol extract displayed reduction in temperature against typhoid vaccine-induced pyrexia model in rabbits when compared with paracetamol (100 $\mathrm{mg} \mathrm{kg}{ }^{-1}$, p.o.) at the doses of 200 and $400 \mathrm{mg} \mathrm{kg}^{-1}$ [116].

\section{Anxiolytic activity}

Moniruzzaman et al. [29] examined the neuropharmacological potential of methanolic extract of $\mathrm{C}$. nurvala leaves using various behavioral models in animals and identified potentially active phytochemicals in this plant extract. This study showed that this plant extract possesses sedative and anxiolytic potential which could be beneficial in treatment of anxiety and insomnia associated with different psychological disorders [29].

\section{Nootropic activity}

Ethanolic extracts of C. nurvala stem bark (100, 200, and $400 \mathrm{mg} \mathrm{kg}^{-1}$ body weight) reduced acetyl cholinesterase activity in rat brain when compared with standard drug Piracetam. The results indicate that ethanolic extract of $C$. nurvala might be useful as a nootropic agent to delay the onset and reduce the severity of symptoms associated with dementia and Alzheimer's disease [108].

\section{Wound healing activity}

The C. nurvala root bark ethanol extract (150 and 300 $\mathrm{mg} \mathrm{kg}^{-1}$, p.o.) showed the healing of wound in vivo as well as in vitro [117].

Therefore, further in-depth studies are needed to understand the precise molecular mechanisms underlying the observed pharmacological activities of the isolated the bioactive phytochemical(s).

\section{Conservation of $C$. nurvala}

C. nurvala Buch.-Ham is a medicinally important tree, and the root and stem bark of this tree have been the main ingredients of various pharmaceutical products [118]. Having a high medicinal value with marvelous applications and even if, extensive work has been carried out to exploit the therapeutic significance of this plant, huge prospects still exists in novel areas. Discovering more and newer usages of this plant puts leads to increasing stress on current natural yield of this plant. To encounter the rising demand for plant material, recognizing best genetic varieties and developing mass multiplication rates through conventional and biotechnological/genetic engineering techniques becomes more imperative. Moreover, optimization of climatic conditions and development of suitable agrotechniques would improve the quality and quantity of the overall yield, thus promising a higher compensation to the cultivators. Greater economic earnings by cultivating superior-quality planting material would definitely boost the agrarians to commence commercial cultivation of $C$. nurvala, hence restricting the overexploitation of this plant in the wild and thereby complementing the conservation process [13].

\section{Future scope of $C$. nurvala}

The ethanolic extract of $C$. nurvala has shown nootropic effect [108] which may reduce the severity of symptoms associated with dementia and Alzheimer's disease. Acetylcholinesterase is involved in the termination of impulse transmission by rapid hydrolysis of the neurotransmitter acetylcholine in numerous cholinergic pathways in the central and peripheral nervous systems. The enzyme inactivation, induced by various inhibitors, leads to acetylcholine accumulation, hyperstimulation of nicotinic and muscarinic receptors, and disrupted neurotransmission. Cholinesterase inhibitors are clinically used to improve learning and memory abilities, mood, and behavior in those neurodegenerative diseases [119, 120]. Since this drug has anxiolytic potential in previous studies [29], more studies on different parts C. nurvala are required to explore its role in CNS disorders and to elucidate the role of reported chemical constituents in psychosomatic disorders along with mechanism of actions so that this highly exploited ayurvedic medicinal plant can be developed into a medicine with confirmed therapeutic effect on the health.

\section{Conclusion}

The profuse growth of $C$. nurvala in subtropical Himalayan range ensures the availability of this plant at economic cost for its use as herbal complementary medicine. These days, people are heeding back for the utilization of herbal plants in combating routine health problems because of fewer adverse effects and cheap prices as well. The information gathered in this review reveals that $C$. nurvala, commonly called Varuna, enjoys a respectable place in several materia medica which in turn might be due to its wide range of pharmacological applications in several ailments. Previous research work suggests that this plant or its isolated bioactives can show potential efficacy against chronic conditions like cancer, cardiovascular complications, inflammation, 
diabetes, and kidney dysfunctions. Betulinic acid, catechin, diosgenin, friedelin, kaempferol, quercetin, and rutin are some of important therapeutically active phytoconstituents of $C$. nurvala. In this complied work, it seems that $C$. nurvala and its phytoconstituents may be used as bioactives in the treatment of several ailments and can be developed in to a complimentary herbal medicine.

\section{Abbreviations}

FCA: Freund's complete adjuvant; MDA: M.D. Anderson; MB: Metastasis breast; p.o.: Per orally

\section{Acknowledgements \\ Not applicable.}

\section{Authors' contributions}

We declare that this work was done by the authors named in this article: DK conceived and designed the study. SS carried out the literature collection of the data and writing of the manuscript. SK assisted in the data analysis and corrected the manuscript. All the authors read and approved the final manuscript.

\section{Funding}

Not applicable.

\section{Availability of data and materials}

All the information in the manuscript has been referred from the included references and is available upon request from the corresponding author.

\section{Ethics approval and consent to participate}

Not applicable.

\section{Consent for publication}

Not applicable.

\section{Competing interests}

The authors declare that they have no competing interests.

Received: 3 July 2020 Accepted: 2 September 2020

Published online: 02 December 2020

\section{References}

1. Abelson PH (1990) Medicine from plants. Science 247:513-514

2. Farnsworth NR, Akerele O, Bingel AS (1985) Medicinal plants in therapy. Bull World Health Organ 63:965-981

3. Gakuya DW, Okumu MO, Kiama SG, Mbaria JM, Gathumbi P, Mathiu PM, Nguta JM (2020) Traditional medicine in Kenya: past and current status, challenges and the way forward. Scientific Afr 8:1-7 https://doi.org/10.1016/ j.sciaf.2020.e00360

4. Akerele O (1993) Summary of WHO guidelines for the assessment of herbal medicine. Herbalgram 28:13-16

5. Shu YZ (1998) Recent natural products based drug development: a pharmaceutical industry perspective. J Nat Prod 61:1053-1071

6. Graul Al (2001) The year's new drugs. Drug News Perspect 14:12-31

7. Kumar D (2016) PhD dissertation "Chemical and biological screening of selected medicinal plants". Kurukshetra University, Kurukshetra

8. Bhattacharjee A, Sashidhara SC, Aswathanarayana (2012) Phytochemical and ethno-pharmacological profile of C. nurvala Buch-Hum (Varuna): a review. Asian Pac J Trop Biomed 2:S1162-68.13-4

9. Modi PR, Kolhapure SA (2004) Evaluation of clinical efficacy and safety of Himplasia in BPH: a prospective, randomized, placebo-controlled, double blind, phase III clinical trial. Medicine Update 12(6):33-42

10. Deshpande P, Sahu M, Kumar P (1982) Crataeva nurvala hook and Forst (Varuna) the Ayurvedic drug of choice in urinary disorders. Indian J Med Res 76(suppl):46-53

11. Warrier PK (1997) Indian medicinal plants: a compendium of 500 species., Vol. 4, Arya V. S. (Ed.). Orient Publication, France
12. Rao VG, Annamalai T, Mukhopadhyay T (2011) Chemical examination and biological studies on the bark of Crataeva nurvala Buch.-Ham. Pharm J 3:1-4

13. Bopana N, Saxena S (2008) Crataeva nurvala: a valuable medicinal plant. J Herbs Spices Med Plants 14(1-2):107-127 https://doi.org/10.1080/ 10496470802341532

14. Pullaih T (2006) Encyclopedia of world medicinal plants. Regency Publication, New Delhi

15. Panda H (2004) Handbook of medicinal plants. Asia Pacific Publication, Delhi

16. Warrier PK (1995) Indian medicinal plants: a compendium of 500 species, Arya VS (Ed). Orient Publication, France

17. Anonymous (2004) The wealth of India, vol 2. Cl-Cy, NISCAIR, Council of Scientific and Industrial Research, New Delhi

18. Nadkarni KM, Nadkarni AK (2009) Indian materia medica, vol 1. Popular Prakashan, Bombay

19. Remya MB, Somnath M, Santosh N, Manayat R, Samuel S, Jolly (2009) Crataeva nurvala, a valuable medicinal plant in the treatment of benign prostatic hyperplasia, Kerala Ayurveda Vaidyam.

20. Soosamma J, Madhavi T, Raj B, Shaji J, Vinutha (2010) Phytochemistry and pharmacology of an important Indian medicinal plant Crataeva nurvala Buch Ham. Res J Pharmacogn Phytochem 2:275-280

21. Kirtikar KR, Basu BD (2005) Indian medicinal plants, vol 1, 2nd edn. International Book Publisher, Dehradun

22. Bal N, Chaubey S, Tiwari RC, Kour GD, Dhyani S (2016) Varun (Crataeva nurvala Buch-Ham): a critical review with respect to urinary tract disorder. Int J Ayurveda Pharma Res 4:49-51

23. Chopra RN, Chopra IC, Varma BS (1969) Supplement to glossary of Indian medicinal plants. CSIR Publication, New Delhi

24. Khatter V, Wal P (2012) Utilities of Crataeva nurvala. Int J Pharm Pharm Sci 4: $21-26$

25. Sastry JLN (2001) Ayurvedokta Oushadha Nirukta Mala, Ist edn. Jaikrishn Ayurveda Granthmala, Delhi

26. Sastry JLN (2005) Dravyaguna Vijnana. Part-II, 2nd edn. Chaukhamba Orientalia, Varanasi

27. Tripathi I (2006) Raja Nighantu, 4th edn. Chaukhambha Krishna Das Academy, Varanasi

28. Chunekar KC, Pandey GS (2009) Bhavaprakash Nighantu. Chaukambha Bharati Academy, Varanasi

29. Moniruzzaman M, Mannan MA, Hossen Khan MF, Abir AB, Afroze MA (2018) The leaves of Crataeva nurvala Buch-Ham. modulate locomotor and anxiety behaviors possibly through GABAergic system. BMC Compl Alternative Med $18: 1-12$

30. Sahoo S, Mishra SK, Panda PK, Tripathy S, Mishra SR, Ellaiah P, Dah SK (2008) Antimycotic potential of Crataeva Religiosa Hook and Forst against some selected fungal pathogens. Acta Pol Pharm 65:245-247

31. Walia N, Kaur A, Babbar SB (2007) An efficient, in vitro cyclic production of shoots from adult trees of Crataeva nurvala Buch. Ham. Plant Cell Rep 26: 277-284

32. Sanayaima RK, Kaur A, Agrawal A, Babbar SB (2006) Cryopreservation of in vitro-grown shoot tips of Crateva nurvala Buch. Ham., an important medicinal tree. Cryo-Letters 27:375-386

33. Gagandeep M, Khalidhar SK (2006) Chemical constituents of C. nurvala (Buch-Ham) leaves. Indian J Pharm Sci 68:804-806

34. Ghani A (2003) Medicinal plants of Bangladesh with chemical constituents and uses, 2nd edn. Asiatic Society of Bangladesh, Dhaka

35. Singh A, Singh PK (2009) An ethnobotanical study of medicinal plants in Chandauli district of Uttar Pradesh, India. J Ethnopharmacol 121:324-329

36. Chopra RN, Nayer SL, Chopra IC (1956) Glossary of Indian medicinal plants. CSIR, New Delhi

37. Kumari A, Kakkar P (2008) Screening of antioxidant potential of selected barks of Indian medicinal plants by multiple in vitro assays. Biomed Environ Sci 21:24-29

38. Kumar DG, Deepa P, Rathi MA, Meenakshi P, Gopalkrishnan VK (2012) Modulatory effects of Crataeva nurvala bark against testosterone and Nmethyl-N-nitrosourea-induced oxidative damage in prostate of male albino rats. Pharmacogn Mag 8:285-291

39. Lakshmi V, Chauhan JS (1975) Triterpenoids and related compounds from Crataeva nurvala. Planta Med 27:254-256

40. Buckingham J (1994) Dictionary of natural products, 1st edn. Chapman and Hall, London

41. Heilbron I et al (1965) Dictionary of organic compounds. Eyre and Spottiswoode, London 
42. Sukhdev (1989) Handbook of terpenoids, vol II. CRC Press, Florida

43. Catherine EU (2015) An evidence-based systematic review of Beta-sitosterol, Sitosterol (22,23dihydrostigmasterol, 24-ethylcholesterol) by the Natural Standard Research Collaboration. J Diet Suppl 13:35-92 https://doi.org/10 3109/19390211.2015.1008812

44. Bouic PJ, Clark A, Lamprecht J, Freestone M, Pool EJ, Liebenberg RW et al (1999) The effects of B sitosterol (BSS) and B-sitosterol glucoside (BSSG) mixture on selected immune parameters of marathon runners: inhibition of post-marathon immune suppression and inflammation. Int J Sports Med 20: 258-262

45. Bouic PJ, Clark A, Brittle W, Lamprecht JH, Freestone M, Liebenberg RW (2001) Plant sterol/sterolin supplement use in a cohort of South African HIVinfected patients-effects on immunological and virological surrogate markers. S Afr Med J 91:848-850

46. Louw I, Halland A, Bouic PJD, Freestone MW, Lamprecht JH (2002) A pilot study of the clinical effects of a mixture of beta-sitosterol and beta-sitosterol glucoside in active rheumatoid arthritis (RA). Nutrition Week Congress, Abstract

47. Li CR, Zhou Z, Lin RX, Zhu D, Sun YN et al (2007) Beta-sitosterol decreases irradiation-induced thymocyte early damage by regulation of the intracellular redox balance and maintenance of mitochondrial membrane stability. J Cell Biochem 102:748-758

48. Imanaka H, Koide H, Shimizu K, Asai T, Shimizu KN et al (2008) Chemoprevention of tumor metastasis by liposomal betasitosterol intake. Biol Pharm Bull 31:400-404

49. Moghaddam MG, Ahmed JBH, Samzadeh-Kermani A (2012) Biological activity of betulinic acid: a review. Pharmacol Pharm 3:119-123

50. Chandramu C, Manohar RD, Krupadanam DGL, Dashavantha RV (2003) Isolation, characterization and biological activity of betulinic acid and ursolic acid from Vitex negundo L. Phytother Res 17:129-134

51. Aiken C, Chen CH (2005) Betulinic acid derivatives as HIV-1 antivirals. Trends Mol Med 11:31-36

52. Yogeeswari P, Sriram D (2005) Betulinic acid and its derivatives: a review on their biological properties. Curr Med Chem 12:657-666

53. Gautam R, Jachak SM (2009) Recent development in anti-inflammatory natural products. Med Res Rev 29:767-820

54. Kim J, Lee YS, Kim CS, Kim JS (2012) Betulinic acid has an inhibitory effect on pancreatic lipase and induce adipocyte lipolysis. Phytother Res 26:11031106

55. Rajendran $P$, Jaggi M, Singh MK, Mukerjee $R$, Burman AC (2008) Pharmacological evaluation of C-3 modified betulinic acid derivatives with potent anticancer activity. Invest New Drugs 26:25-34

56. Zhang X, Hu J, Chen Y (2016) Betulinic acid and the pharmacological effects of tumor suppression (Review). Mol Med Rep 14:4489-4495

57. Silva FS, Oliveria PJ, Duarte MF (2016) Oleanolic, ursolic, and betulinic acids as food supplements or pharmaceutical agents for type 2 diabetes: promise or illusion? J Agric Food Chem 64:2991-3008

58. Susanti E, Ciptati RR, Aulanni'am RA (2015) Qualitative analysis of catechins from green tea GMB-4 clone using HPLC and LC-MS/MS. Asian Pac J Trop Biomed 5:1046-1050

59. Gadkari PV, Balaraman M (2015) Catechins: Sources, extraction and encapsulation: A review. Food Bioprod Process 93:122-138

60. Reygaert WC (2018) Green tea catechins: Their use in treating and preventing infectious diseases. Biomed Res Int 2018:1-9 https://doi.org/10. 1155/2018/9105261

61. Santos-Buelga C, Scalbert A (2000) Proanthocyanidins and tannin-like compounds-nature, occurrence, dietary intake and effects on nutrition and health. J Sci Food Agric 80:1094-1117

62. Riso P, Erba D, Criscuoli F, Testolin G (2002) Effect of green tea extract on DNA repair and oxidative damage due to $\mathrm{H} 2 \mathrm{O} 2$ in Jurkat T cells. Nutr Res 22:1143-1150

63. Finger A, Engelhadt UH, Wray V (1991) Flavonol triglycosides containing galactose in tea. Phytochemistry 30:2057-2060

64. Sethi G, Shanmugam MK, Warrier S, Merarchi M, Arfuso F, Kumar AP (2018) Bishayee A (2018) Pro-apoptotic and anti-cancer properties of Diosgenin: A comprehensive and critical review. Nutrients 10:645 https://doi.org/10.3390/ nu10050645

65. Long C, Chen J, Zhou H, Jiang T, Fang X, Hou D, Liu P, Duan H (2019) Diosgenin exerts its tumor suppressive function via inhibition of $\mathrm{Cdc} 20$ in osteosarcoma cells. Cell Cycle 18:346-358
66. Yang WS, Moon SY, Lee MJ, Lee EK, Park SK (2017) Diosgenin, an activator of 1,25D3-MARRS receptor/ERp57, attenuates the effects of TNF-alpha by causing ADAM10-dependent ectodomain shedding of TNF receptor 1. Cell Physiol Biochem 43:2434-2445

67. Son IS, Kim JH, Sohn HY, Son KH, Kim JS, Kwon CS (2007) Antioxidative and hypolipidemic effects of diosgenin, a steroidal saponin of Yam (Dioscorea spp.), on high-cholesterol fed rats. Biosci Biotechnol Biochem 71:3063-3071

68. Lee BK, Kim CJ, Shin MS, Cho YS (2018) Diosgenin improves functional recovery from sciatic crushed nerve injury in rats. J Exerc Rehabil 14:566572

69. Pi WX, Feng XP, Ye LH, Cai BC (2017) Combination of Morroniside and Diosgenin prevents high glucose induced cardiomyocytes apoptosis. Molecules 22:163 https://doi.org/10.3390/molecules22010163

70. Raju J, Mehta R (2009) Cancer chemopreventive and therapeutic effects of diosgenin, a food saponin. Nutr Cancer 6:27-35

71. Sunil C, Duraipandiyan V, Ignacimuthu S, Al-Dhabi NA (2013) Antioxidant, free radical scavenging and liver protective effects of friedelin isolated from Azima tetracantha Lam. leaves. Food Chem 139(1-4):860-865 https://doi. org/10.1016/j.foodchem.2012.12.041

72. Russo EB, Marcu J (2017) Cannabis Pharmacology: The usual suspects and few promising leads. Adv Pharmacol 80:67-134

73. Bishayee A, Ahmed S, Brankov N, Perloff M (2011) Triterpenoids as potential agents for the chemoprevention and therapy of breast cancer. Front Bioscience 16:980-996

74. Susanti D, Amiroudine MZ, Rezali MF, Taher M (2013) Friedelin and lanosterol from Garcinia prainiana stimulated glucose uptake and adipocytes differentiation in 3T3-L1 adipocytes. Nat Prod Res 27:417-424 https://doi.org/10.1080/14786419.2012.725399

75. Chinsembu KC (2016) Tuberculosis and nature's pharmacy of putative antituberculosis agents. Acta Tropica 153:46-56

76. Antonisamy P, Duraipandiyan V, Aravinthan A, NA AI-D, Ignacimuthu S, Choi KC, Kim JH (2015) Protective effects of friedelin isolated from Azima tetracantha Lam. against ethanol-induced gastric ulcer in rats and possible underlying mechanisms. Eur J Pharmacol 750:167-175

77. Lee J, Ha SK, Kim Y, Choi I (2017) Effects of friedelin on the intestinal permeability and bioavailability of apigenin. Pharmacol Rep 69:1044-1048 https://doi.org/10.1016/j.pharep.2017.04.012

78. Calderón-Montaño JM, Burgos-Morón E, Pérez-Guerrero C, López-Lázaro M (2011) A review on the dietary flavonoid kaempferol. Mini Rev Med Chem 11:298-344

79. Imran M, Salehi B, Sharfi-Rad J, Gondal TA, Saeed F, Imran A, Shahbaz M, Tsouh Fokou PV, Umair AM, Khan H, Guerreiro SG, Martins N, Estevinho LM (2019) Kaempferol: A key emphasis to its anticancer potential. Molecules 24: 2277:1-16 https://doi.org/10.3390/molecules24122277

80. Mekhala DK, Vithana ZS, Stuart KJ (2019) Regulation of the levels of health promoting compounds: lupeol, mangiferin and phenolic acids in the pulp and peel of mango fruit: a review. J Sci Food Agric 99:3740-3751

81. Surh YJ (2003) Cancer chemoprevention with dietary phytochemicals. Nature Rev Cancer 3:768-780

82. Sunitha S, Nagaraj M, Varalakshmi P (2001) Hepatoprotective effect of lupeol and lupeol linoleate on tissue antioxidant defense system in cadmiuminduced hepatotoxicity in rats. Fitoterapia 72:516-523

83. Latos-Brozio M, Maseka A (2019) Structure-activity relationships analysis of monomeric and polymeric polyphenols (Quercetin, Rutin and Catechin) obtained by various polymerization methods. Chem Biodiversity 16(12): e1900426

84. D'Andrea G (2015) Quercetin: A flavonol with multifaceted therapeutic applications? Fitoterapia 106:256-271

85. Andres S, Pevny S, Ziegenhagen R, Bakhiya N, Schäfer B, Hirsch-Ernst K, Lampen A (2018) Safety aspects of the use of Quercetin as a dietary supplement. Mol Nutr Food Res 62:170044 https://doi.org/10.1002/mnfr. 201700447

86. Marunaka Y, Marunaka R, Sun H, Yamamoto T, Kanamura N, Inui T, Taruno A (2017) Actions of Quercetin, a Polyphenol, on blood pressure. Molecules 22: 209 https://doi.org/10.3390/molecules22020209

87. Gullon B, Lú-Chau TA, Moreira MT, Lema JM, Eibes G (2017) Rutin: A review on extraction, identification and purification methods, biological activities and approaches to enhance its bioavailability. Trends Food Sci Technol 67: 220-235

88. Kim KH, Lee KW, Kim DY, Park HH, Kwon IB, Lee HJ (2005) Optimal recovery of high-purity rutin crystals from the whole plant of Fagopyrum esculentum 
Moench (buckwheat) by extraction, fractionation, and recrystallization. Bioresour Technol 96:1709-1712

89. Janbaz KH, Saeed SA, Gilani AH (2002) Protective effect of rutin on paracetamol and $\mathrm{CCl} 4$-induced hepatotoxicity in rodents. Fitoterapia 73 : 557-563

90. Richetti SK, Blank M, Capiotti KM, Piato AL, Bogo MR, Vianna MR, Bonan CD (2011) Quercetin and rutin prevent scopolamine-induced memory impairment in zebrafish. Behav Brain Res 217:10-15

91. Ganeshpurkar A, Saluja AK (2017) The Pharmacological Potential of Rutin. Saudi Pharm J 25:149-164

92. Xie X, Zhang Z, Wang $X$ et al (2018) Stachydrine protects eNOS uncoupling and ameliorates endothelial dysfunction induced by homocysteine. Mol Med 24(1):10 https://doi.org/10.1186/s10020-018-0010-0

93. Cheng F, Yanxi Z, Wanga M, Guoa C, Caoa Z, Zhanga R, Penga C (2020) A review of pharmacological and pharmacokinetic properties of Stachydrine. Pharmacol Res 155:104755 https://doi.org/10.1016/j.phrs.2020.104755

94. Zhang RH, Liu ZK, Yang DS, Zhang XJ, Sun HD, Xiao WL (2018) Phytochemistry and pharmacology of the genus Leonurus: The herb to benefit the mothers and more. Phytochemistry. 147:167-183 https://doi.org/ 10.1016/j.phytochem.2017.12.016

95. Cho YC, Ju A, Kim BR, Cho S (2015) Anti-inflammatory effects of Crataeva nurvala Buch. Ham. are mediated via inactivation of ERK but not NF-KB. J Ethnopharmacol 162:140-147

96. Margareth BCG, Miranda JS (2009) Biological activities of lupeol. Intl J Biomed Pharm Sci 3:46-66

97. Geetha T, Varalakshmi P (1999) Anticomplement activity of triterpenes from C. nurvala stems bark in adjuvant arthritis in rats. Gen Pharmacol 32:495-497

98. Fernández MA, de las Heras B, García MD, Sáenz MT, Villar A (2001) New insights into the mechanism of action of the anti-inflammatory triterpene lupeol. J Pharm Pharmacol 53:1533-1539

99. Nguemfo EL, Dimo T, Dongmo AB, Azebaze AG, Alaoui K, Asongalem AE, Cherrah Y, Kamtchouing P (2009) Anti-oxidative and anti-inflammatory activities of some isolated constituents from the stem bark of Allanblackia monticola Staner L.C. (Guttiferae). Inflammopharmacology 17:37-41

100. Saleem M (2009) Lupeol, A novel anti-inflammatory and anti-cancer dietary triterpene. Cancer Lett 285:109-115

101. Bhaskar VH, Profulla KM, Balakrishnan BR, Balakrishnan N, Sangameswaran B (2009) Evaluation of the antifertility activity of stem bark of C. nurvala BuchHum. Afr J Biotechnol 8:6453-6456

102. Siddique HR, Saleem M (2011) Beneficial health effects of lupeol triterpenes: a review of preclinical studies. Life Sci 88:285-293

103. Latha RM, Lenin M, Rasool M, Varalakshmi P (2001) A novel derivative pentacyclic triterpene and $\dot{\omega}-3$ fatty acid [Lupeol-EPA] in relation to lysosomal enzymes glycoproteins and collagen in adjuvant induced arthritis in rats. Prostag Leukotr Ess 64:81-85

104. Inayathulla SWR, Karigar AA, Sikarwar MS (2010) Evaluation of anti-diarrhoeal activity of root bark of Createva nurvala in experimental animals. Int J Pharm Pharm Sci 2:158-161

105. Sudharsan PT, Mythili Y, Selvakumar E, Varalakshmi P (2005) Cardioprotective effect of pentacyclic triterpene, lupeol and its ester on cyclophosphamideinduced oxidative stress. Hum Exp Toxicol 24:313-318

106. Johri R, Singh D, Johri PK (2010) Study of hypolipidemic activity of selected medicinal plant extracts in normal and induced hyperlipidemic rats. Biochem Cell Arch 10:215-224

107. Agarwal S, Gupta SJ, Saxena AK, Gupta N, Agarwal S (2010) Urolithic property of Varuna (C. nurvala): An experimental study. Ayu 31:361-366

108. Bhattacharjee A, Shashidhara SC, Saha S (2015) Nootropic activity of Crataeva nurvala Buch-Ham against Scopolamine induced cognitive impairment. EXCLI J 14:335-345

109. Patankar S, Dobhada S, Bhansali M, Khaladkar S, Modi J (2008) A prospective, randomized, controlled study to evaluate the efficacy and tolerability of Ayurvedic formulation "Varuna and Banana stem" in the management of urinary stones. J Altern Complement Med 14:1287-1290

110. Alam MA, Haque ME, Shilpi JA, Daulla KA (2006) Antinociceptive effect of the crude ethanolic extract of C. nurvala Buch. on mice. Bangl J Vet Med 4: 65-68

111. Sikarwar MS, Patil MB (2010) Antidiabetic activity of C. nurvala stem bark extracts in alloxan-induced diabetic rat. J Pharm Bioall Sci 2:18-21

112. Das P, Sethi R, Mekap S, Pani S (2010) Phytochemical and pharmacological screening of plant C. magna alloxan induced diabetes in rats. J Pharm Sci Res 2:257-263
113. Lee TK, Poon RT, Wo JY, Ma S, Guan XY, Myers JN, Altevogt P, Yuen AP (2007) Lupeol suppresses cisplatin-induced nuclear factor-kappa B activation in head and neck squamous cell carcinoma and inhibits local invasion and nodal metastasis in an orthotopic nude mouse model. Cancer Res 67:88008809

114. Zhang L, Zhang Y, Zhang L, Yang X, Lv Z (2009) Lupeol, a dietary triterpene inhibited growth, and induced apoptosis through down-regulation of DR3 in SMMC7721 cells. Cancer Invest 27:163-170

115. Wagh NS, Gaikwad NJ (2014) Evaluation of anti-cancer activity of bark of C. nurvala Buch Ham. against cell lines. Int J Pharm Sci Res 5:4851-4857

116. Chidambaram K, Albert J, Karpagam K, Sivasubramanian N (2011) Antipyretic activity of Crataeva magna bark on Tab-Vaccine induced pyrexia. Int J Pharm Sci Res 2:856-859

117. Asuti N (2010) Wound healing property of alcoholic extract of root bark of C. nurvala. J Pharm Res 3:1121-1123

118. MM, Nataraj M (2020) In vitro regeneration competency of Crataeva nurvala (Buch Ham) callus. Vegetos 33:52-62 https://doi.org/10.1007/s42535-01900080-x

119. Sibi PI, Delphia PG (2013) Nootropic studies of ethanolic extract of Mimosa pudica Linn. in albino wistar rats. Am J Phytomed Clin Therap 1:266-275

120. Mirjana B. Colovic, Danijela Z. Krstic, Tamara D. Lazarevic-Pasti, Aleksandra M. Bondzic, Vesna M. Vasic (2013) 11(3):315-335

\section{Publisher's Note}

Springer Nature remains neutral with regard to jurisdictional claims in published maps and institutional affiliations.

\section{Submit your manuscript to a SpringerOpen ${ }^{\circ}$ journal and benefit from:}

- Convenient online submission

- Rigorous peer review

- Open access: articles freely available online

- High visibility within the field

- Retaining the copyright to your article

Submit your next manuscript at $\boldsymbol{\nabla}$ springeropen.com 